\title{
Preliminary determination of the energy potential of ocean currents along the southern coast of Brazil
}

\author{
Andrea Fischer, Alexandre Beluco, Luiz Emílio B. de Almeida \\ Inst Pesquisas Hidráulicas, Univ Fed Rio Grande do Sul, Porto Alegre, Brazil.
}

\begin{abstract}
The ocean can be a strategic alternative for obtaining energy supplies, both from ocean waves as from sea currents and tides. Among these features, the power generation projects based on ocean currents are still under development. Generating energy from ocean can have great impact on the Brazilian energy grid, since Brazil has a vast coastline, with more than $9,000 \mathrm{~km}$ long, with potential for generating energy from ocean currents not fully estimated. This article presents a preliminary determination of the energy potential for power generation from ocean currents along the coast of Rio Grande do Sul, the southernmost state of Brazil, and also presents notes that contribute to the characterization of the system of ocean currents in the region. The data used were obtained in two areas near Tramandaí, allowing the determination of velocities and directions of the currents on a seasonal basis. The maximum speeds obtained rarely exceed $0.750 \mathrm{~m} / \mathrm{s}$, while the average speeds do not exceed $0.200 \mathrm{~m} / \mathrm{s}$. A relationship with the prevailing winds in the region was identified. Unfortunately, the results do not allow optimism about the power generation from ocean currents on the southern coast of Brazil, at least over the continental shelf.
\end{abstract}

Copyright $@ 2013$ International Energy and Environment Foundation - All rights reserved.

Keywords: Ocean energy; Ocean current energy; Survey of energetic potential; Southern coast of Brazil.

\section{Introduction}

The ocean can be a strategic alternative for obtaining energy supplies, both from ocean waves as from ocean currents and tides. Among these possibilities, the power generation projects based on ocean currents are still under development.

The expansion of renewable energy can contribute to the diversification of energy supplies, encourage new businesses, create jobs and contribute to the development of disadvantaged regions, offering several environmental advantages when compared to traditional sources of power generation.

In this scenario, it can be possible to consider that the plants generating energy from ocean currents can contribute in meeting the energy needs causing little environmental impacts, pollution-free air and with competitive costs of implementation and operation.

The ocean is capable of providing energy supplies from six forms of energy: wave power, energy obtained from the vertical movement caused by tides; kinetic energy of the water, both ocean currents as the movement caused by tides through passages in the coastal region, the energy obtained from the temperature difference and energy obtained from the salinity difference.

Generating power from the kinetic energy of ocean currents can have great impact on the Brazilian energy grid, since Brazil has a vast coastline, with more than 9,000 km long, with potential for 
generating energy from ocean currents not fully estimated. There are few points with potential for tidal power generation, but the great length of coast magnifies the potential of ocean currents.

Among all these forms of energy, only the energy of the waves approaches to achieve technical and economic maturity. Forms of energy obtainable tides have reasonable development, mainly by being available in places where other resources appear scarce. The current energy still requires development, primarily for the use of lower flow velocity.

This article presents a preliminary determination of the energy potential for power generation from ocean currents along the coast of Rio Grande do Sul, the southernmost state of Brazil, based on data obtained with current meters, as described in the following chapters. This article also presents notes that contribute to the characterization of the system of ocean currents in the region as part of a project that aims to establish the feasibility of obtaining energy from the ocean [1].

\section{Energy from ocean currents}

The evaluation of the potential energy present in ocean currents is similar to the assessment of wind energy. The advantages are the predictability of the strength and direction of the current density and the fact that the water specific weight is about 1000 times greater than that of air, allowing the use of smaller equipment than wind turbines. As disadvantages have been small flow velocities and the adverse characteristics of the marine environment [2].

The fraction of energy extracted from the ocean currents by a conversion device, E [W], can be understood from equation (1), where $\mathrm{v}[\mathrm{m} / \mathrm{s}]$ is the current velocity, $\Phi_{\mathrm{v}}[1]$ is the probability of a velocity in the range $(\mathrm{v}+\mathrm{dv}), \mathrm{T}[\mathrm{s}]$ is the period, $\mathrm{P}_{\mathrm{T}}[\mathrm{W}]$ is the rated power, $\mathrm{A}\left[\mathrm{m}^{2}\right]$ is the area of the scanning device, $\rho\left[\mathrm{kg} / \mathrm{m}^{3}\right]$ is the specific weight of water and $C_{p}[1]$ is the power coefficient.

$$
E=\int_{v=0}^{\infty} E_{v} d v=\int_{v=0}^{\infty}\left(\Phi_{v} T\right) P_{T} d v=\int_{v=0}^{\infty} A\left[\frac{1}{2} \rho v^{3} C_{p}\left(\Phi_{v} T\right)\right] d v
$$

where as $\rho$ and $\mathrm{C}_{\mathrm{p}}$ are constant, the average power drawn by the equipment can be written according to equation (2).

$$
\frac{E}{T}=P_{T}=\frac{1}{2} \rho A C_{p} \int_{v=0}^{\infty} \Phi_{v} v^{3} d v
$$

If the scanning area of the device (or hydrofoil blades) is not sufficiently known, it is possible to calculate the power per unit area, known as power density, $\mathrm{p}\left[\mathrm{W} / \mathrm{m}^{2}\right]$, according to equation (3).

$$
\mathrm{p}=\frac{\mathrm{P}_{\mathrm{T}}}{\mathrm{A}}=\frac{1}{2} \rho \mathrm{C}_{\mathrm{p}} \int_{\mathrm{v}=0}^{\infty} \Phi_{\mathrm{v}} \mathrm{v}^{3} \mathrm{dv}
$$

The calculation of power density for a specific stream velocity can then be performed according to equation (4).

$$
\mathrm{p}=\frac{1}{2} \rho \mathrm{C}_{\mathrm{p}} \mathrm{v}^{3}
$$

Following the methodology proposed by Twidell and Weir [2], analyzing the power density was made through the power distribution throughout the data set. In this analysis, the density of seawater $(\rho)$ was found equal to $1,025 \mathrm{~kg} / \mathrm{m}^{3}$ and the coefficient $C_{p}$ equal to 1 , resulting in equation (5).

$$
\mathrm{p}=512.5 \mathrm{v}^{3}
$$




\section{Evaluating the energy resource}

The southernmost coast of Brazil is quite regular, with a length of about $600 \mathrm{~km}$ and a continental shelf width approximately constant and of the order of $160 \mathrm{~km}$. It is a coast with a few cuts and that makes it very difficult to approaching vessels. In the seventeenth and eighteenth centuries, at a time when the region was contested by Spanish and Portuguese, the difficulty imposed by the coast offered respect and gave the name "Neutral Field".

The energy potential of ocean currents near the coast of Rio Grande do Sul was evaluated using two sets of data obtained on the northern coast of Rio Grande do Sul, in southern Brazil Continental Shelf. Figure 1 shows the region where the measurements were made. The first set was collected between 1995 and 1996, while the second data set was obtained in 1963.

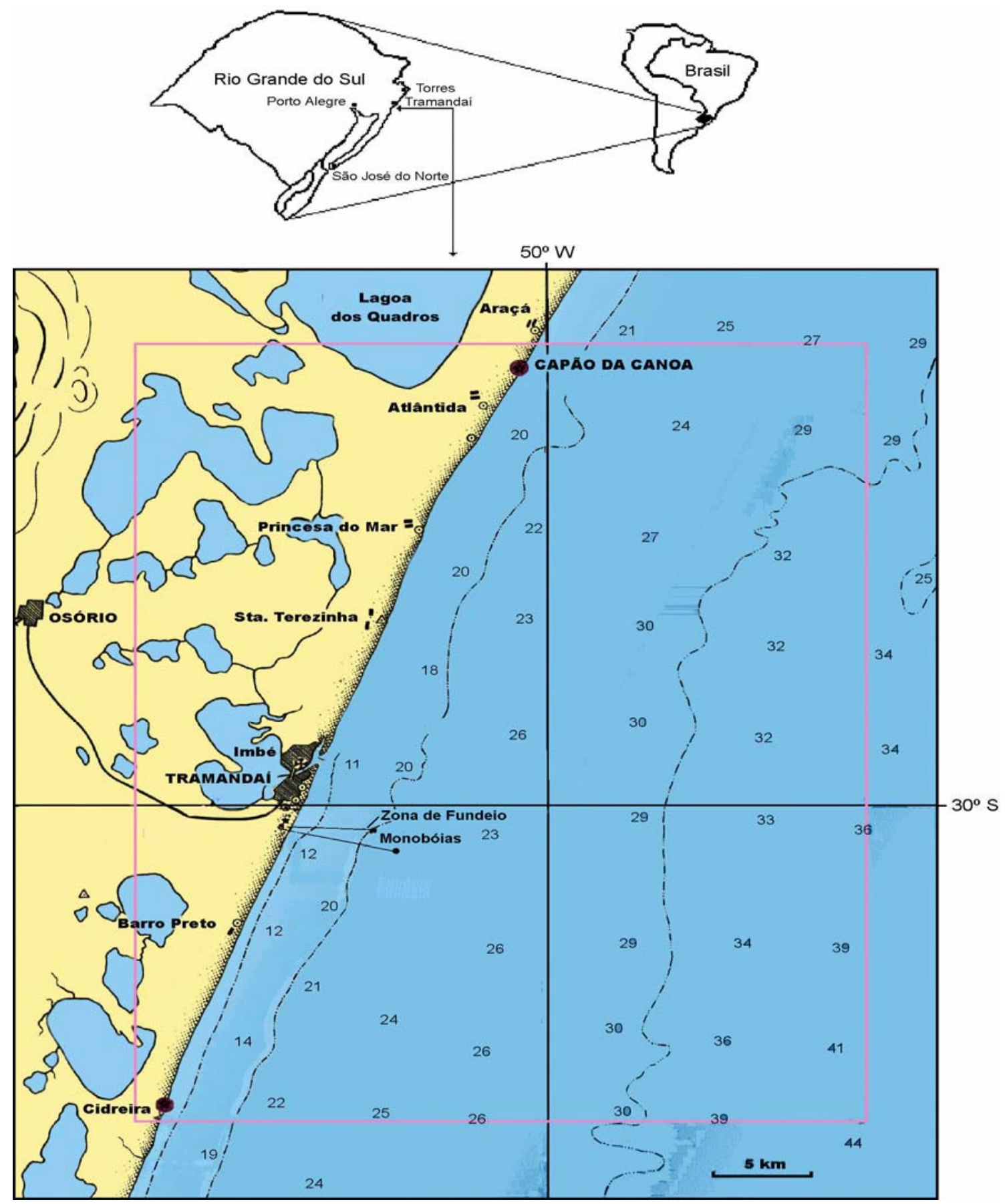

Figure 1. Location of current meter off the coast of Rio Grande do Sul, in southern Brazil. [3] 
The data from 1995 and 1996 were collected in the region of Tramandaí, 30o00'42"S and 50 o 06'21"W. Measurements were obtained with two current meters SensorData brand, model SD6000, installed at a point approximately 2,500 meters from the beach line and with an average depth of $18 \mathrm{~m}$, respectively anchored to 5 meters and 15 meters from the bottom. As failures occurred during data acquisition, they were divided seasonally for analysis.

Data collected in 1963 were obtained in the region of Imbé near the point of collection of the first data set at 9 meters from the bottom in area with an average depth of $18 \mathrm{~m}$. The survey period was from January 25 to March 13.

Because wind is an important factor in the analysis of the directions of the currents, were evaluated for their predominant directions. The wind data considered were obtained from a meteorological station of the brand Campbell, only for the months of 1996 in Tramandaí. The meteorological station was installed near the Ferry Terminal Almirante Soares Dutra, 29 o58'34"S and 50 o07'25"W, and data speed and wind direction were obtained at 15 meters high.

The region has a rectilinear coastline, oriented northeast - southwest, forming an angle of approximately $22^{\circ}$ inclination to the Magnetic North. The bathymetry of this region is quite soft, with greater slope and shelf break located at about 180 meters, having a tendency to extension of the continental shelf to the south, characteristic of the continental margin of South America [4].

\section{Results and discussion}

Data were analyzed and divided according to the quota in which they were collected: 5 meters and 15 meters from the bottom, for 1995 and 1996, and 9 meters from the bottom, for 1963. The predominant direction was determined by analyzing the current compasses for each season, repeated for wind data for months with available information. The current compasses and wind compasses shown in the following figures were determined with the software Matlab [5].

Figure 2 shows the current compasses obtained 5 meters from the bottom, for spring 1995 and summer and winter1996. In the spring of 1995, in (a), the predominant direction was $\mathrm{N}$, with $42.31 \%$ of occurrence, the second most frequent direction was the SSW, with 12, 75\%. In the summer of 1996, (b), the predominant direction is observed SSW, with $33.18 \%$ of the total occurrences and the second is the NNE with $25.65 \%$. Due to problems in the current meter, there are no data records to the fall of 1996 this quota. In the winter of 1996 , (c), the main directions were observed to NNE, with $18.25 \%$ and $16.88 \% \mathrm{~N}$ with the total occurrences.

Figure 3 shows the current compasses obtained at 15 meters from the bottom, for spring 1995, winter, autumn and summer of 1996. The current compass for spring of 1995, in (a), shows that the main directions of the currents are NNE and SSW. The predominant direction was NNE with $36.5 \%$ occurrence, while toward SSW was $14.64 \%$. In (b) shows the compass for summer 1996. During this period, the main directions were observed in the north, with $21.23 \%$ of the total occurrences and SW, with $20.28 \%$. The directions SSW, WSW and NNE were also significant occurrence, with $17.46 \%$, $10.14 \%$ and $8.94 \%$, respectively.

Figure 4 shows the current compass obtained 9 meters from the bottom for the summer of 1963. It is observed that the direction SSW had the highest occurrence (35.29\%) and NNE showed occurrence of $21.18 \%$. Making a comparison with current data from the summer of 1996, shown in Figure 2 (c), we observe that the main directions, SSW and NNE, remain.

The main directions of the winds in the summer months (February and March 1996) occurred in the Northeast sector, as shown in Figure 5, showing that there is an influence of the wind relative to the direction of the currents that occurred significantly in the southwest sector.

In the fall of 1996, the directions were located mostly in the Northwest sector, being the predominant direction North, with $17.57 \%$ of occurrences (Figure 3 (c)). The predominant wind direction in April 1996 was the NE and in May 1996 was the W (Figure 5), it is not possible to establish a relationship with the directions of the currents.

The current compass for winter of 1996 is shown in Figure 3 (d). The predominant direction was NNE. The largest percentage of occurrence for each direction were: $33.6 \%$ in the NNE direction, $20.75 \%$ for SSW, $14.06 \%$ for North and $12.09 \%$ for South The predominant wind direction was west and the second was WSW, also occurring winds significantly in NE (Figure 5), showing a relationship with NNE and SSW currents in this period. 


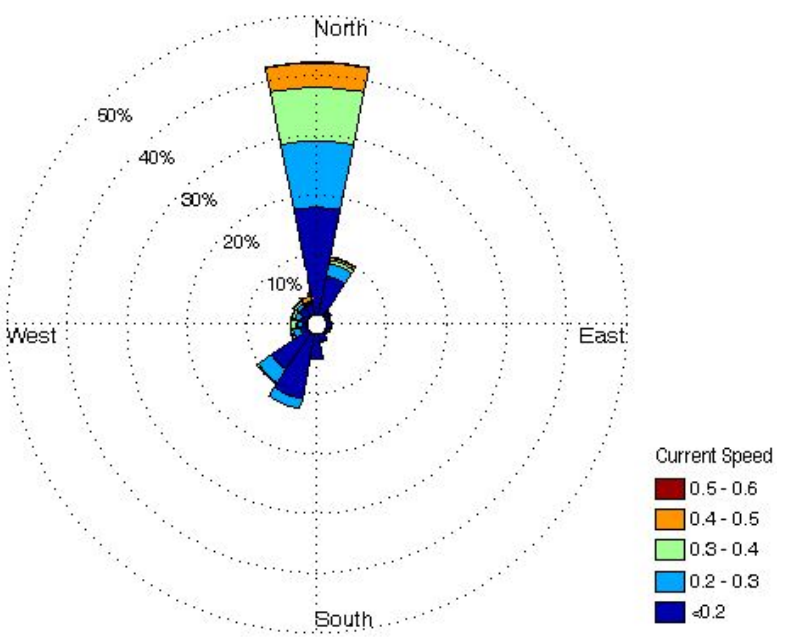

(a)

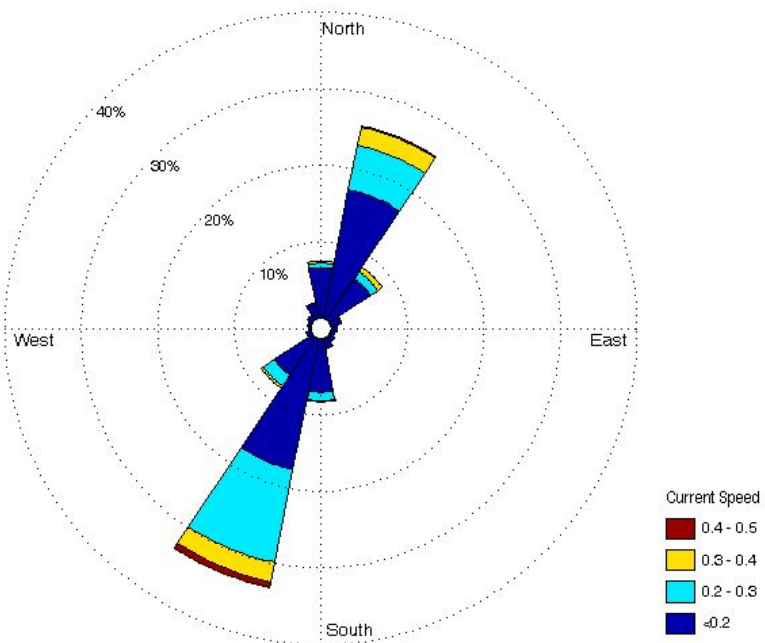

(b)

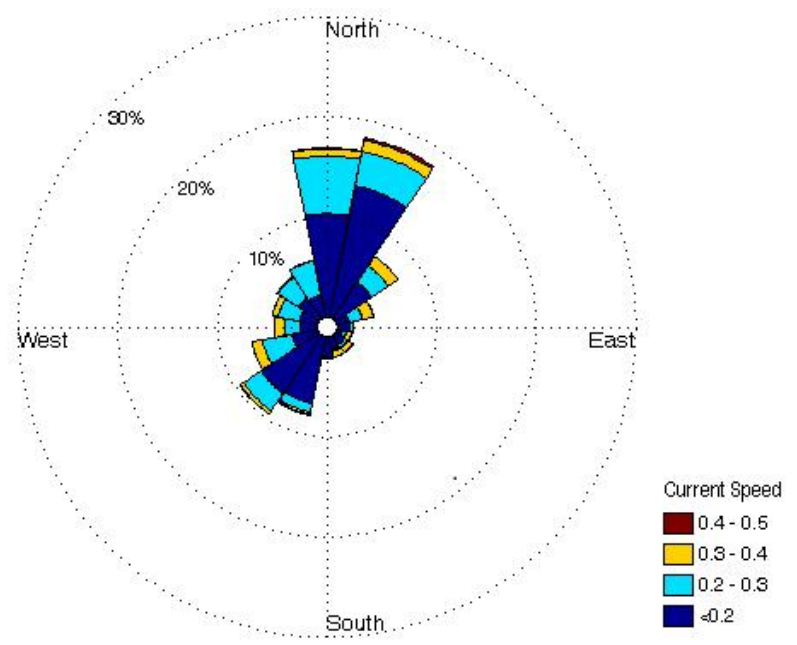

(c)

Figure 2. Current compasses for quota 5 meters, with speeds in $\mathrm{m} / \mathrm{s}$, for: (a) spring 1995, (b) summer 1996 and (c) winter 1996

Data analysis of current direction shows that they vary over time the sector northeast to southwest sector and vice versa. As data were obtained on a place close to the coastline (approximately 2500 meters), it can be said that the behavior of the currents is influenced by the bathymetry, because they have a kind of "spin" and remains parallel in relation to the coastline more frequent in NE-SW direction.

Figure 5 shows the compasses for the months of February, March, April, May, June and July 1996. The pattern of winds over the coastal region is determined by the influence of the South Atlantic anticyclone on the seasonal scale, the presence of synoptic scale weather systems and the system of coastal breeze [6]. NE winds are prevalent on the coast of Rio Grande do Sul, associated with the center of high pressure generated by the semi-stationary anticyclone South Atlantic This system is most intense between spring and summer [7].

According to [8], based on results obtained from a three-dimensional model barotropic and baroclinic forced by river discharge, tides, winds and currents boundary, the region between $28^{\circ} \mathrm{S}$ and $38^{\circ} \mathrm{S}$, the seasonality in the current regime of the inner shelf is evident. In the summer and spring bearing currents have SW depending on the dominance of NE winds. The same seasonal pattern was observed through numerical simulations by [9], who found flows directed to the south and off during the summer.

Between autumn and winter, periodic reversals in wind direction to the south, southwest and southeast are associated with the spread of polar anticyclones to low latitudes (weather fronts), being more frequent in autumn and winter [6]-[10]. Furthermore, [6] report that although the SW component shows a lower frequency of occurrence, this is the one with the highest intensities (between $59 \mathrm{~km} / \mathrm{h}$ to $85 \mathrm{~km} / \mathrm{h}$ ). 
According to [7] southwesterly winds, present in winter, generate an offset to the north. According to [8], in autumn and winter, there is dominance of currents northeast due to higher wind action of SO.

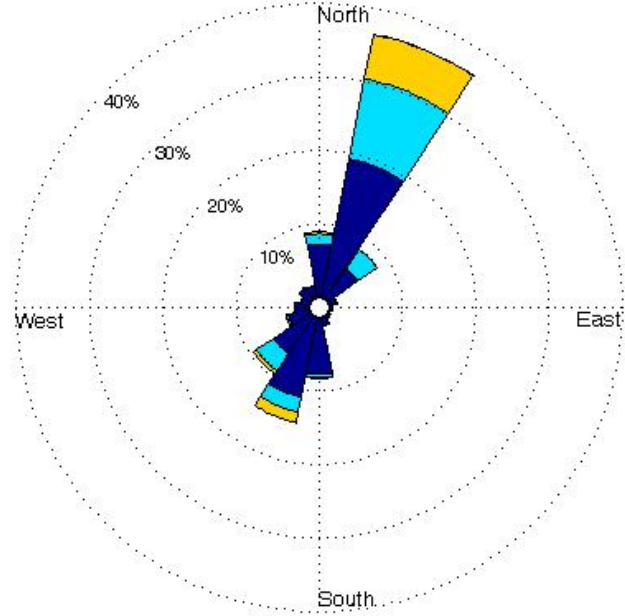

(a)

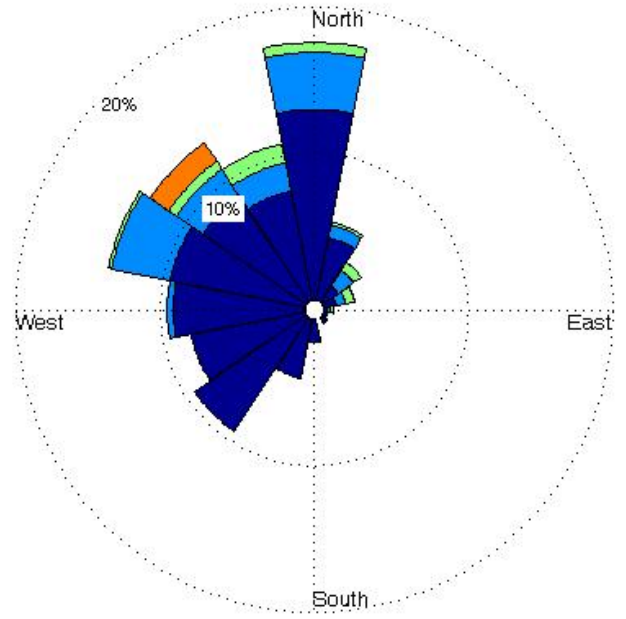

(c)

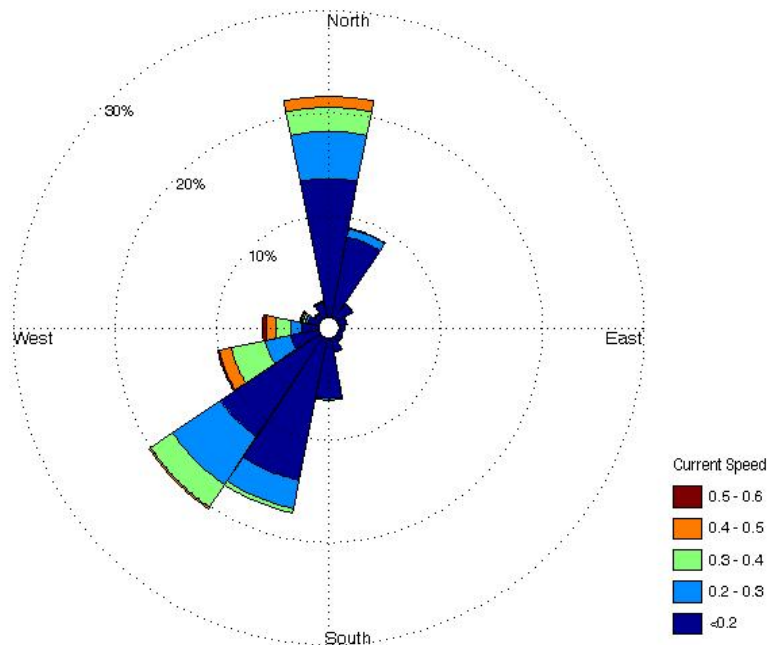

(b)

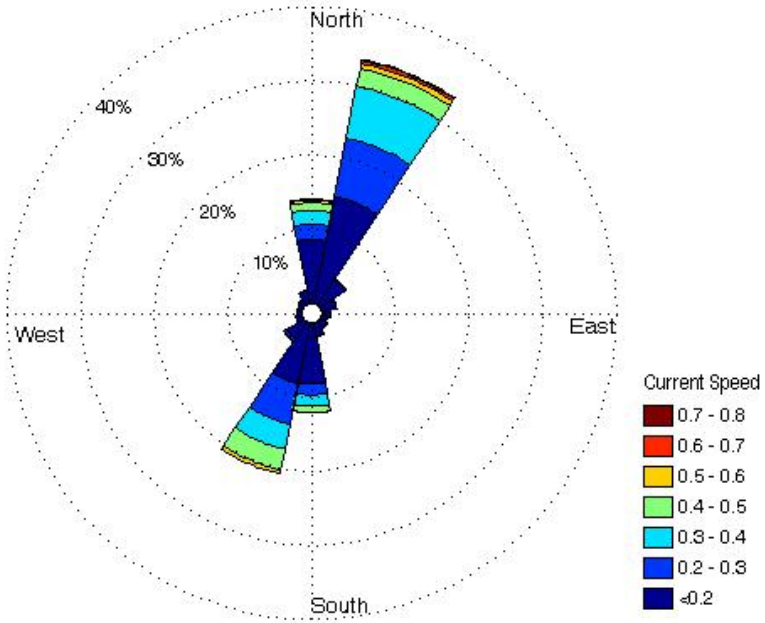

(d)

Figure 3. Current compasses for quota 15 meters, with speeds in $\mathrm{m} / \mathrm{s}$, for: (a) spring 1995, (b) summer 1996, (c) autumn 1996 and (d) winter 1996

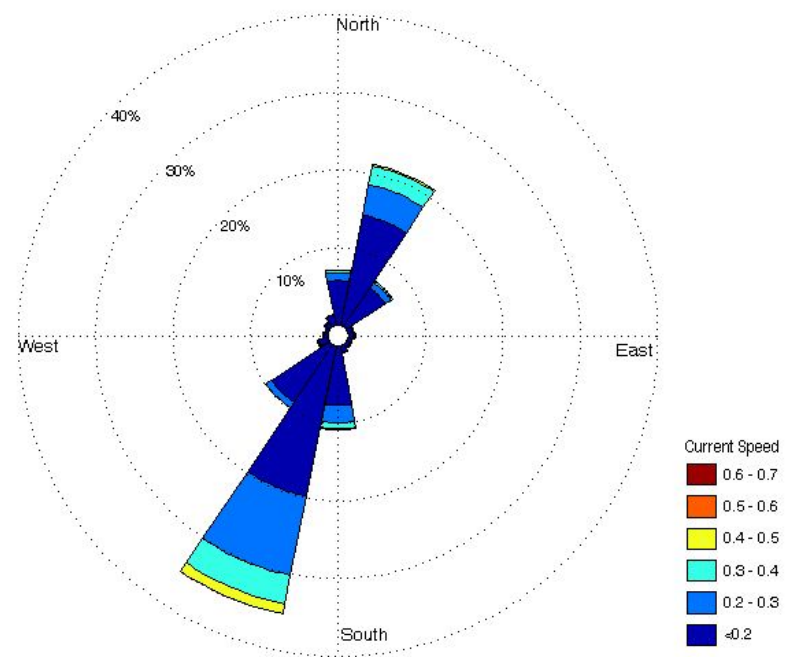

Figure 4. Current compass for quota 9 meters, with speeds in m/s, for summer 1963 


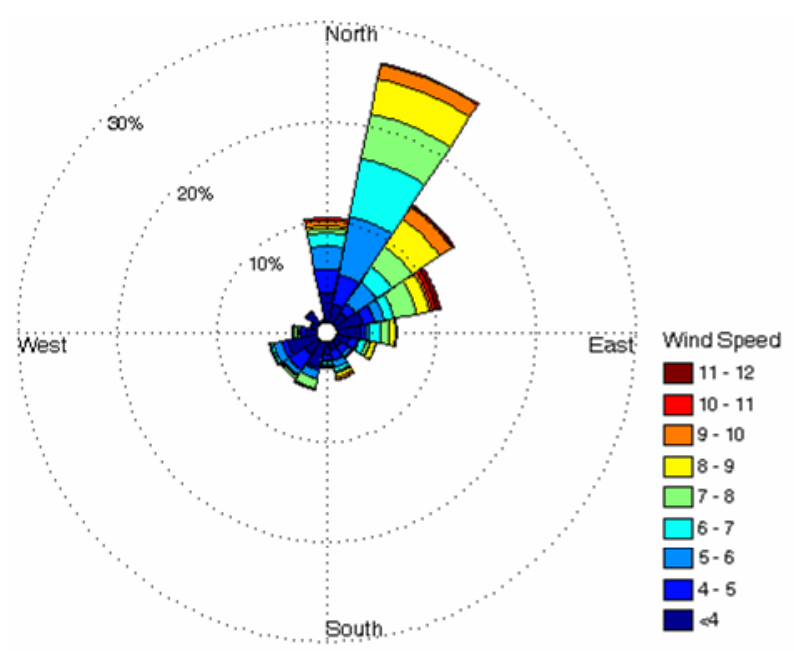

(a)

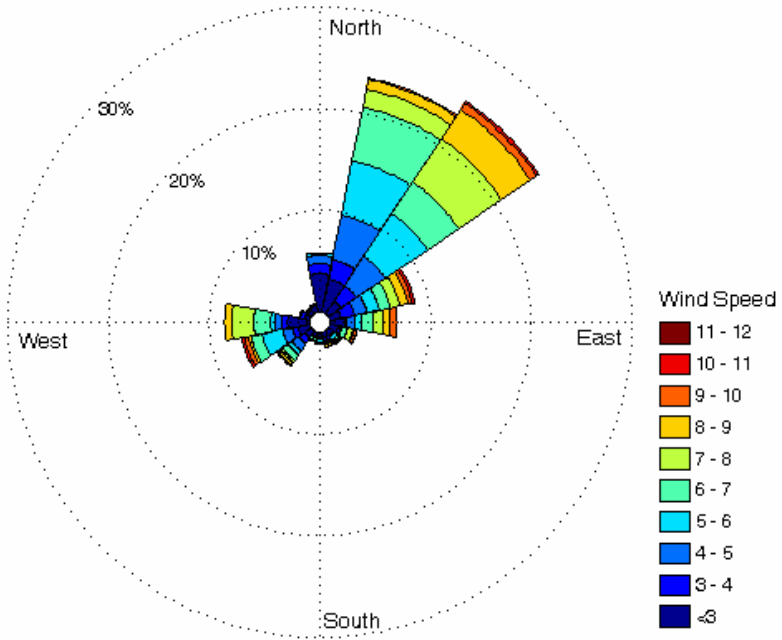

(c)

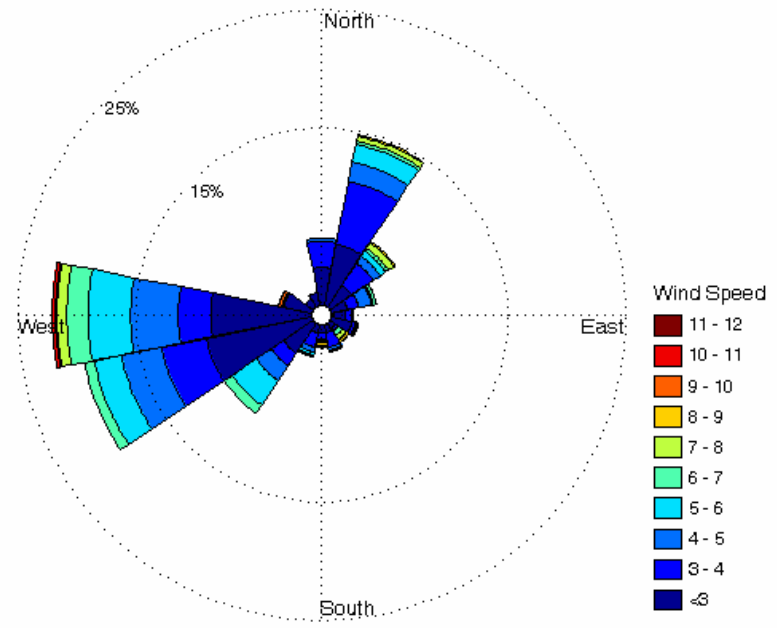

(e)

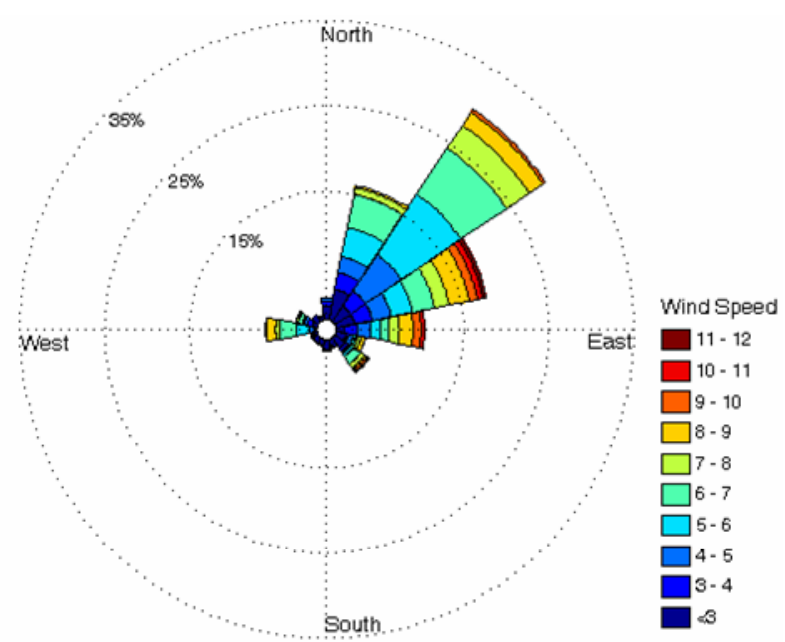

(b)

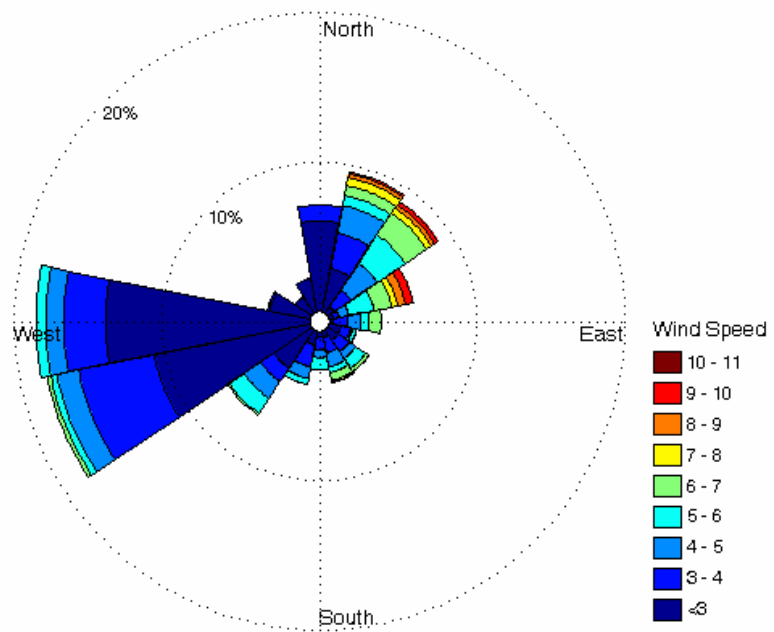

(d)

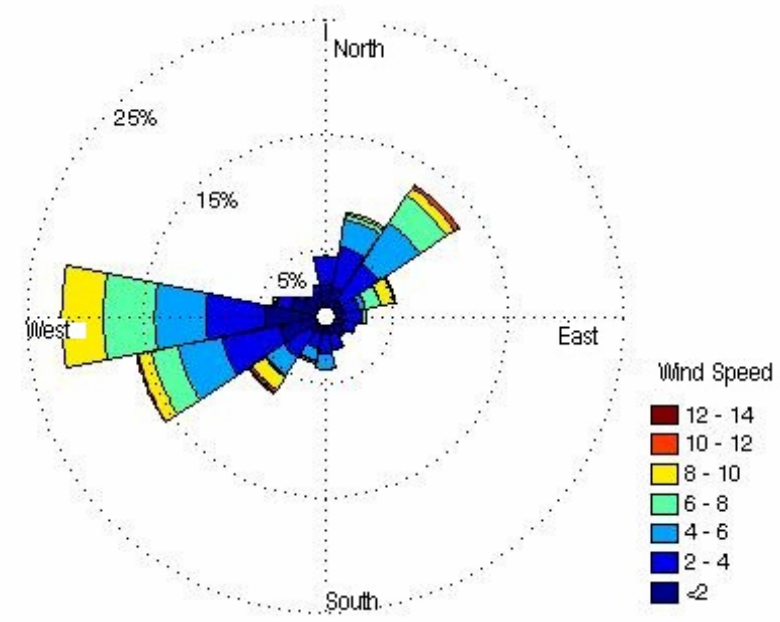

(f)

Figure 5. wind compass, with speeds in m/s, for: (a) February, (b) March, (c) April, (d) May, (e) June and (f) July 1996

The deeper currents for 1995 and 1996 appear in Table 1. The maximum speed was in summer, with 0.54 $\mathrm{m} / \mathrm{s}$. The minimum values are very close to zero. The average maximum also occurs in summer, with 
$0.19 \mathrm{~m} / \mathrm{s}$, assuming a standard deviation of $0.12 \mathrm{~m} / \mathrm{s}$. Figure 6 shows the histograms for the current speeds obtained at 5 meters from the bottom, for spring 1995 and winter and summer 1996.

Table 1. Characterization of current velocity, for the quota of 5 meters, for the period from spring 1995 to winter 1996

\begin{tabular}{lllll}
\hline & Spring & Summer & Autumn & Winter \\
\hline Maximum $(\mathrm{m} / \mathrm{s})$ & 0,540 & 0,460 & - & 0,440 \\
Minimum $(\mathrm{m} / \mathrm{s})$ & 0,004 & 0,002 & - & 0,002 \\
Average $(\mathrm{m} / \mathrm{s})$ & 0,190 & 0,190 & - & 0,170 \\
Standard deviation $(\mathrm{m} / \mathrm{s})$ & 0,120 & 0,090 & - & 0,095 \\
Variation coefficient $(\%)$ & 64,6 & 60,2 & - & 55,6 \\
\hline
\end{tabular}

Table 2 shows the currents closer to the surface, collected at 15 meters from the bottom, between 1995 and 1996. It can be seen that the maximum values are somewhat higher, $0.59 \mathrm{~m} / \mathrm{s}$ in the spring and 0.75 $\mathrm{m} / \mathrm{s}$ in winter, when compared with the results obtained for the depth of 5 meters. Figure 7 shows the histograms for the current speeds obtained at 15 meters from the bottom, for spring 1995, winter, autumn and summer of 1996.

Table 2. Characterization of current velocity, for the quota of 15 meters, for the period from spring 1995 to winter 1996

\begin{tabular}{lllll}
\hline & Spring & Summer & Autumn & Winter \\
\hline Maximum (m/s) & 0,400 & 0,590 & 0,440 & 0,750 \\
Minimum (m/s) & 0,002 & 0,002 & 0,014 & 0,004 \\
Average $(\mathrm{m} / \mathrm{s})$ & 0,160 & 0,170 & 0,140 & 0,190 \\
Standard deviation $(\mathrm{m} / \mathrm{s})$ & 0,090 & 0,110 & 0,090 & 0,140 \\
Variation coefficient $(\%)$ & 56,5 & 67,8 & 65,8 & 72,7 \\
\hline
\end{tabular}

The histogram data speed for spring 1995 (Figure 6 (a)) showed that the most frequent class corresponds to speeds between $0.034 \mathrm{~m} / \mathrm{s}$ and $0.068 \mathrm{~m} / \mathrm{s}$. Already values above $0.5 \mathrm{~m} / \mathrm{s}$ had a lower occurrence. For these data, the Weibull shape parameter (k) was 1.5643 and the scale parameter (c) was $0.2095 \mathrm{~m} / \mathrm{s}$. Velocities above $0.5 \mathrm{~m} / \mathrm{s}$ present $0.025 \%$ probability of occurrence, already speeds below $0.068 \mathrm{~m} / \mathrm{s}$ is likely to $60.2 \%$.

Analyzing the data of surface currents for spring 1995 (Figure 7 (a)), there is a frequency histogram with more balanced profile, with speeds with slightly higher intensity. However, for this data set, the maximum speed was $0.4 \mathrm{~m} / \mathrm{s}$. The adjustment of the Weibull distribution showed a shape parameter $(\mathrm{k})$ of 1.8405 and a scale parameter (c) of $0.1773 \mathrm{~m} / \mathrm{s}$. There is a $1.57 \%$ probability that speeds greater than $0.4 \mathrm{~m} / \mathrm{s}$ might occur.

The histogram of the data at 5 meters from the bottom for the summer of 1996 (Figure 6 (b)) showed that the largest number of data speeds occur in classes of low intensity. The Weibull distribution has shape parameter (k) of 1.7125 and the scale parameter (c) of $0.1729 \mathrm{~m} / \mathrm{s}$. The maximum speed for this dataset is $0.464 \mathrm{~m} / \mathrm{s}$, the probability of occurrence for values greater than $0.4 \mathrm{~m} / \mathrm{s}$ is $1.9 \%$. In Figure 7 (b) at 15 meters from the bottom, the histogram shows that the speed data are the most common lower intensity. As occurred for data deeper currents, the Weibull distribution showed a better fit for speeds with greater intensity, above $0.288 \mathrm{~m} / \mathrm{s}$. The Weibull distribution showed a distribution shape parameter $(\mathrm{k})$ of 1.5347 and a scale parameter (c) of $0.1861 \mathrm{~m} / \mathrm{s}$. The probability of a speed greater than $0.4 \mathrm{~m} / \mathrm{s}$ is $3.69 \%$.

In the fall of 1996 were only collected data on the current 15 meters from the bottom (Figure 7 (c)). The histogram of the data has characteristics similar to other periods analyzed, with higher occurrence of lower speeds. The Weibull distribution has shape parameter $(\mathrm{k})$ of 1.5815 and scale parameter equals $0.1524 \mathrm{~m} / \mathrm{s}$. The adjustment proved to be better for data speeds above $0.3 \mathrm{~m} / \mathrm{s}$. The probability speeds above $0.4 \mathrm{~m} / \mathrm{s}$ is $1.57 \%$. 


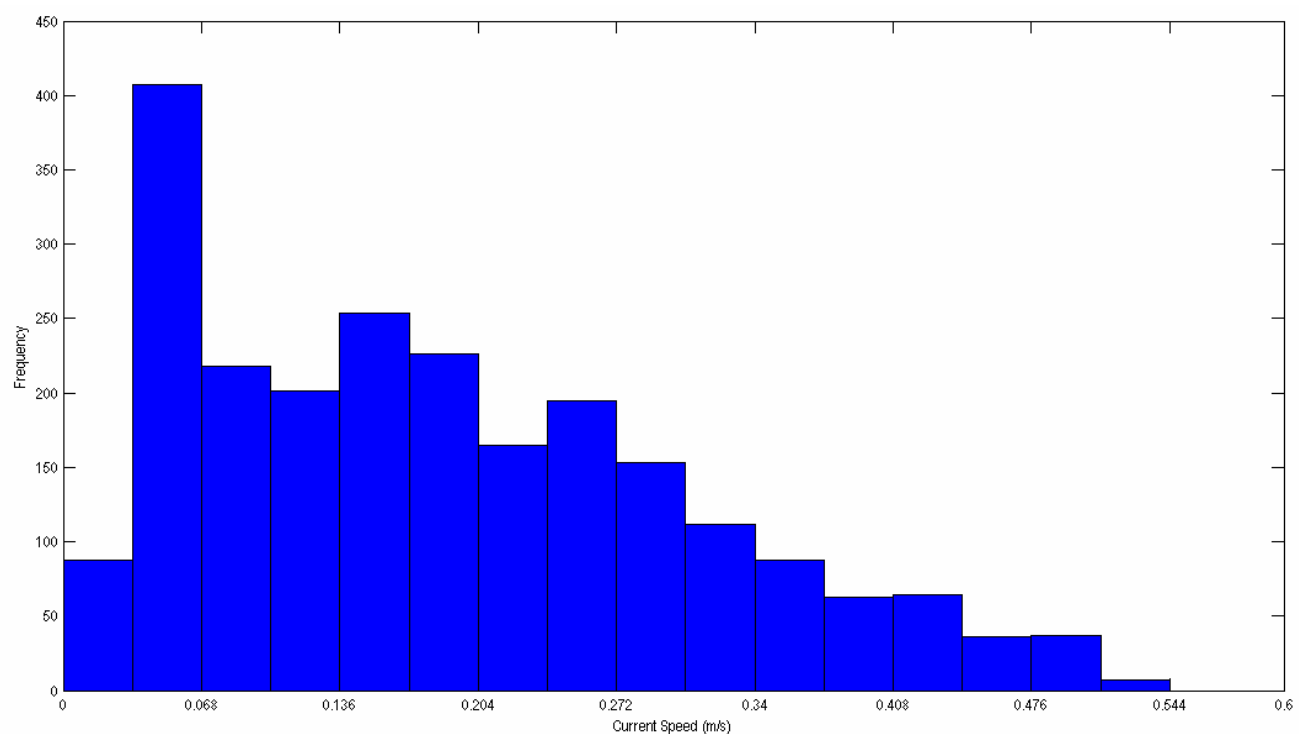

(a)

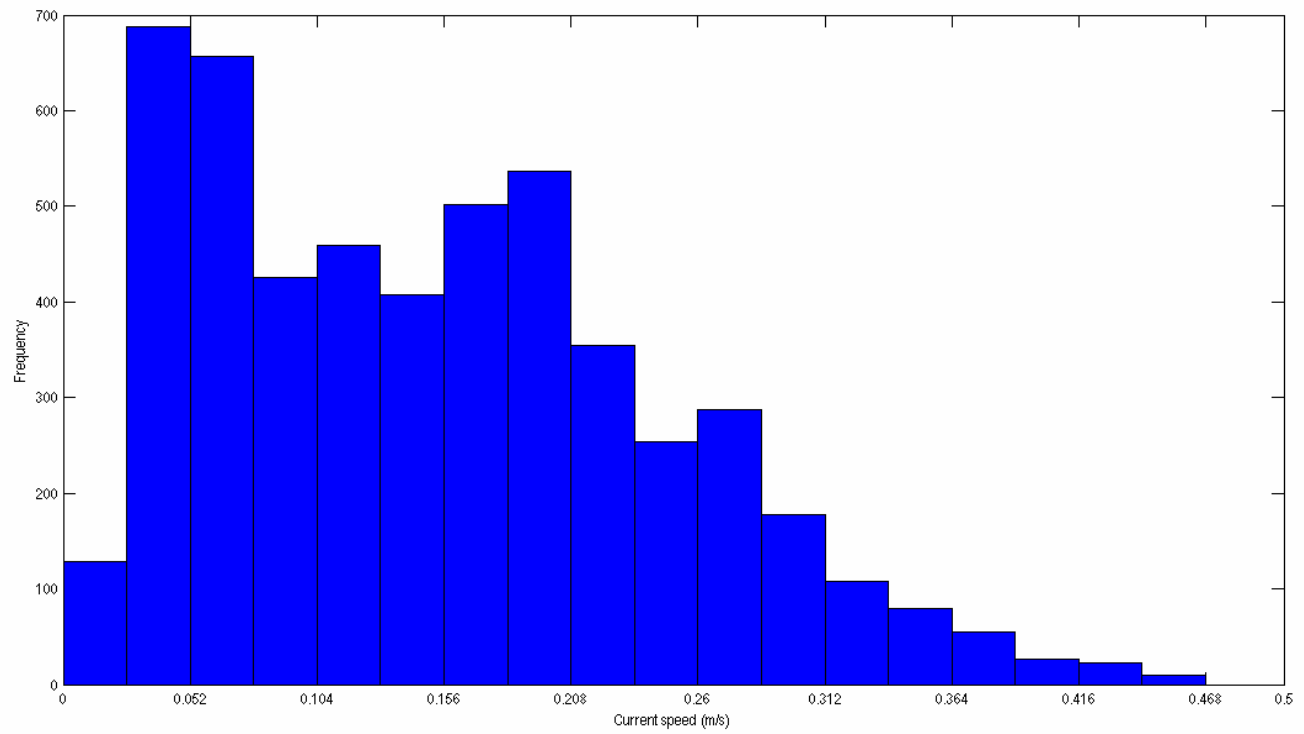

(b)

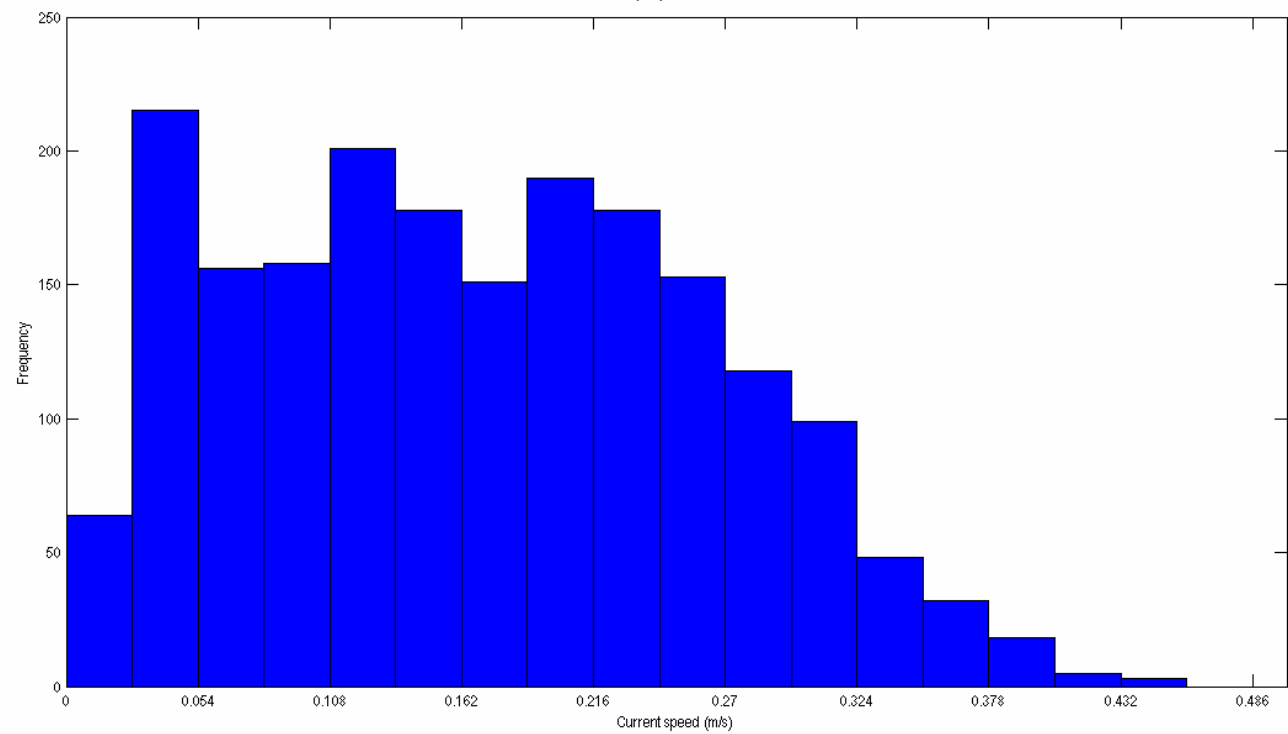

(c)

Figure 6. Histogram of current velocity, for the quota of 5 meters, for: (a) spring 1995, (b) summer and (c) winter 1996 


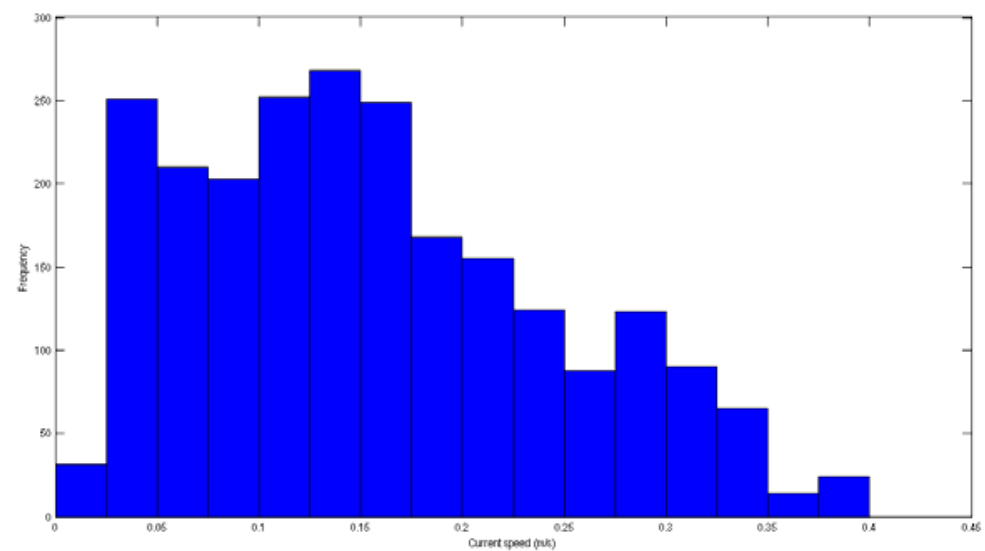

(a)

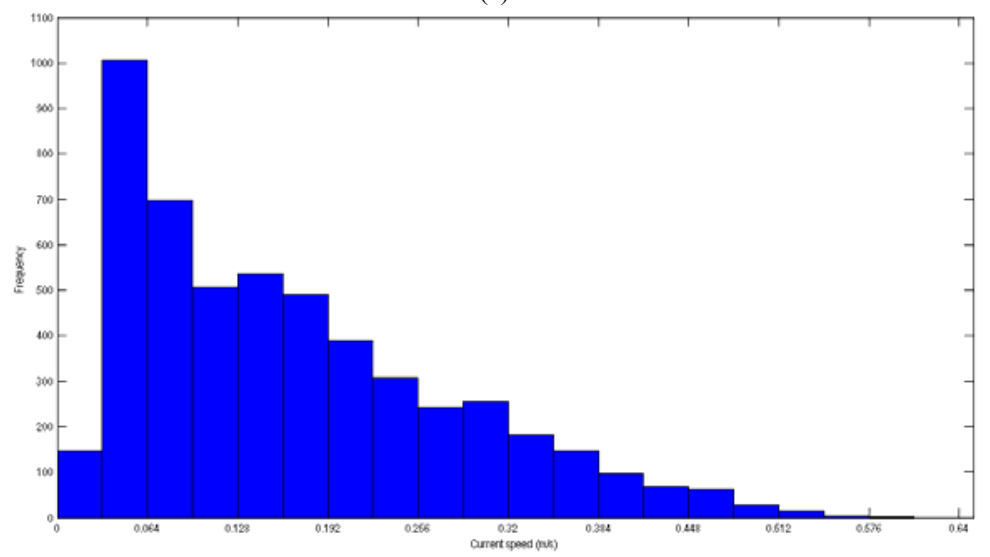

(b)

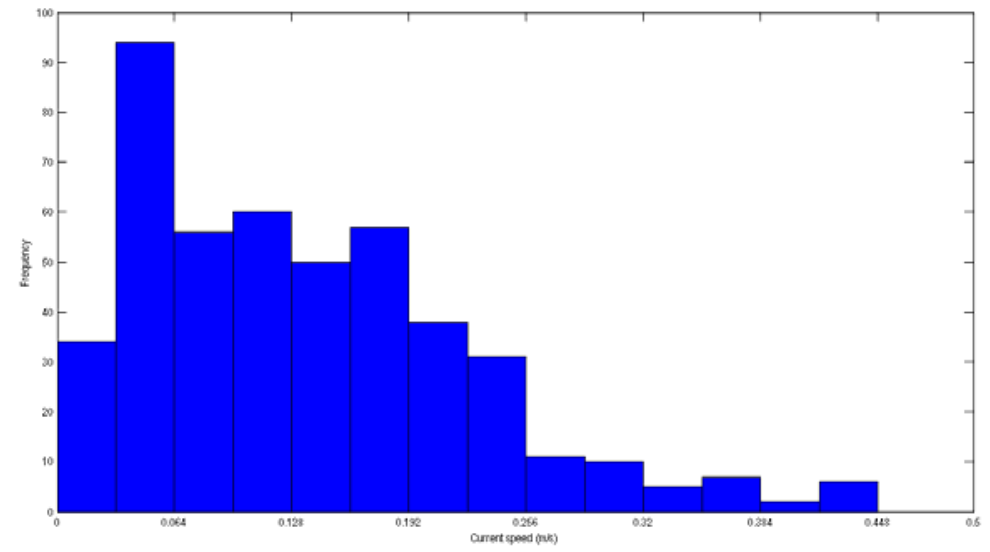

(c)

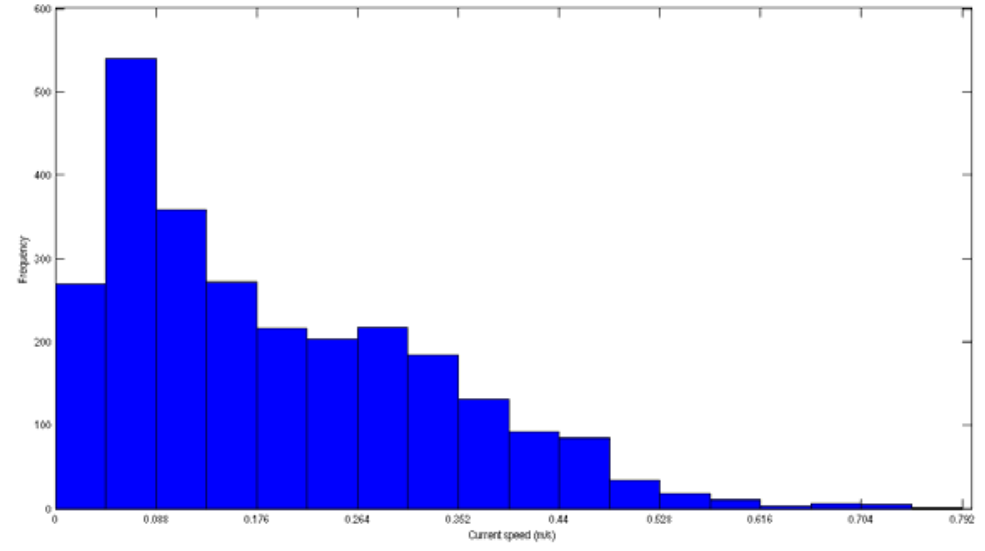

(d)

Figure 7. Histogram of current velocity, for the quota of 15 meters, for: (a) spring 1995, (b) summer, (c) autumn and (d) winter 1996 
The data for 5 meters from the bottom for winter 1996 are shown in the histogram of Figure 6 (c). The Weibull distribution showed shape parameter (k) equals 1.8352 and the scale parameter (c) equals 0.1909 $\mathrm{m} / \mathrm{s}$. The most superficial currents, elevation 15 meters for the winter of 1996 had a higher incidence of low speeds. In histogram (Figure 7 (d)) is possible to observe that the class of speeds between 0.044 and 0.088 showed higher frequency. The Weibull distribution gave shape parameter $(\mathrm{k})$ equals 1.3986 and scale parameter (c) of $0.2111 \mathrm{~m} / \mathrm{s}$. The probability of speeds exceeding $0.4 \mathrm{~m} / \mathrm{s} \mathrm{is} 7.1 \%$.

Figure 8 shows the histogram for the speeds of current data from 1963, obtained during the summer and collected at $9 \mathrm{~m}$ from the bottom. The highest observed velocity was $0.61 \mathrm{~m} / \mathrm{s}$, and the average is very close comparing with data from summer 1996, with $0.18 \mathrm{~m} / \mathrm{s}$ (Table 3). The most common speeds are lower. The Weibull distribution resulted shape parameter $(\mathrm{k})$ equals 1.9885 and the scale parameter equals $0.1849 \mathrm{~m} / \mathrm{s}$. The probability of speeds greater than $0.4 \mathrm{~m} / \mathrm{s}$ is $1.35 \%$.

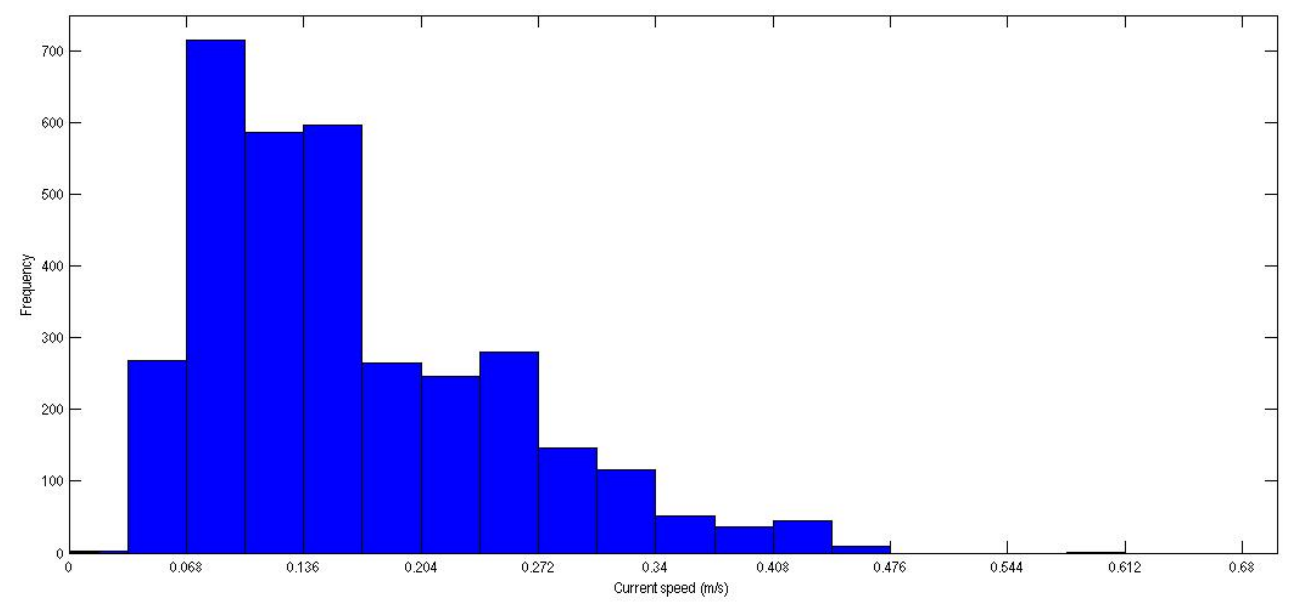

Figure 8. Histogram of current velocity, for the quota of 9 meters, for summer 1963

Table 3. Characterization of current velocity, for the quota of 9 meters, for summer 1963

\begin{tabular}{ll}
\hline Maximum (m/s) & 0,61 \\
Minimum (m/s) & 0,05 \\
Average (m/s) & 0,18 \\
Standard deviation $(\mathrm{m} / \mathrm{s})$ & 0,08 \\
Variation coefficient $(\%)$ & 46,2 \\
\hline
\end{tabular}

Figure 9 shows the power distribution depending on the speed of current and power density as a function of cumulative frequency, 5 meters from the bottom, for the spring of 1995 and summer and winter of 1996. The Figure 9 (a) shows the power distribution for data from spring 1995. During this period, the maximum value of the power distribution is $0.57\left(\mathrm{~W} / \mathrm{m}^{2}\right) /(\mathrm{m} / \mathrm{s})$ and occurs at a speed of $0.44 \mathrm{~m} / \mathrm{s}$. The likelihood of speeds equal to or greater than $0.44 \mathrm{~m} / \mathrm{s}$ is $3.74 \%$. According to the above analysis, the velocities which occur most frequently are between 0.034 and $0.068 \mathrm{~m} / \mathrm{s}$, indicating a restriction for power generation. It is observed that the higher power density is the lowest probability. The average speed of $0.19 \mathrm{~m} / \mathrm{s}$, equivalent to $5 \mathrm{~W} / \mathrm{m}^{2}$, corresponding to a cumulative frequency of 0.46 . As for a speed more significant for power generation, $0.5 \mathrm{~m} / \mathrm{s}$, the power density is $64.1 \mathrm{~W} / \mathrm{m}^{2}$ and the probability of that value equal or exceeded is only $1.38 \%$. For summer 1996, Figure 9 (b) shows the distribution of power with maximum value of $0.24\left(\mathrm{~W} / \mathrm{m}^{2}\right) /(\mathrm{m} / \mathrm{s})$ velocity of $0.28 \mathrm{~m} / \mathrm{s}$. The likelihood of this being equaled or exceeded speed is $6.25 \%$. The average speed for this period is $0.16 \mathrm{~m} / \mathrm{s}$, with a probability of $49 \%$ of the value of power density to be equaled or exceeded $2.1 \mathrm{~W} / \mathrm{m}^{2}$.

The data of the Winter 1996 showed a power distribution according to Figure 9 (c). The maximum value of the distribution was $0.31\left(\mathrm{~W} / \mathrm{m}^{2}\right) /(\mathrm{m} / \mathrm{s})$ for a speed of $0.28 \mathrm{~m} / \mathrm{s}$. The probability of this value being equaled or exceeded is $6.77 \%$. The average velocity is $0.17 \mathrm{~m} / \mathrm{s}$ and cumulative frequency value for this speed is 0.51 , showing a power density of $2.51 \mathrm{~W} / \mathrm{m}^{2}$. 

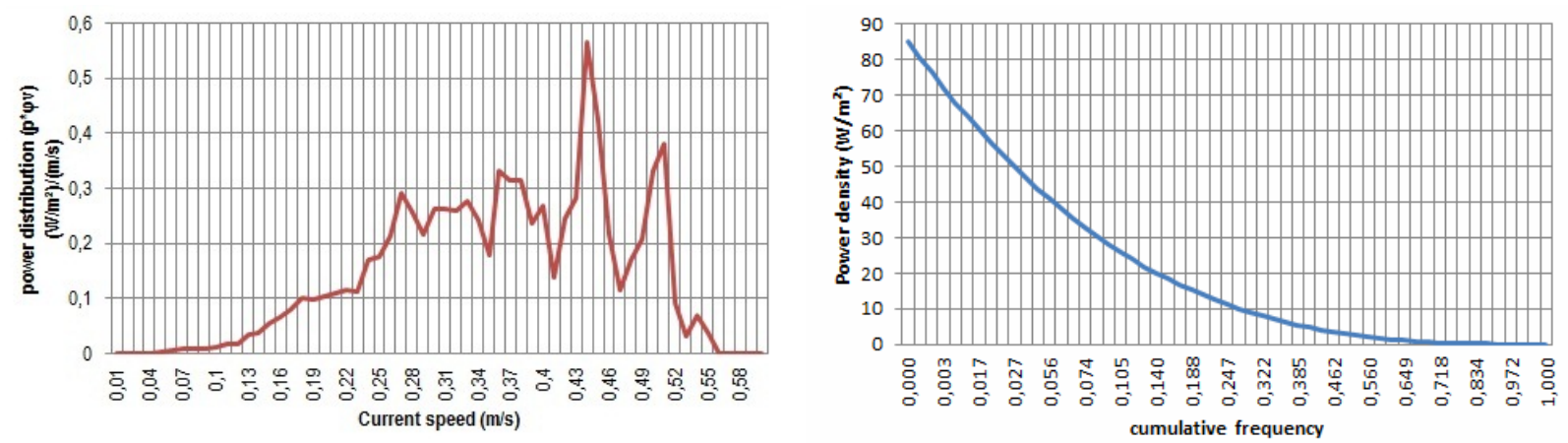

(a)
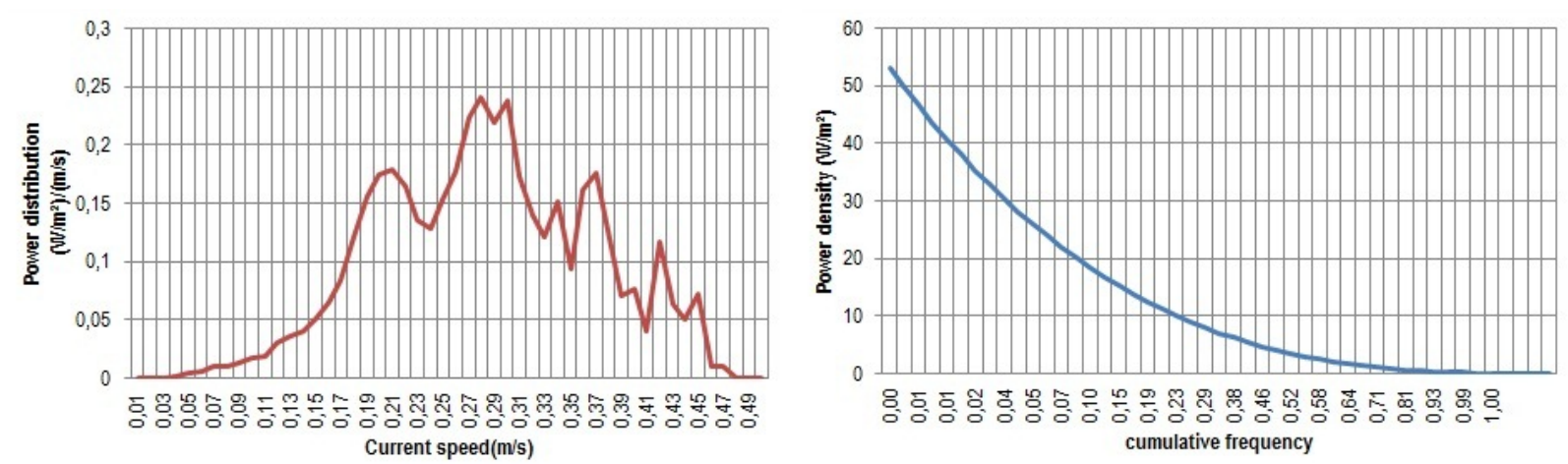

(b)
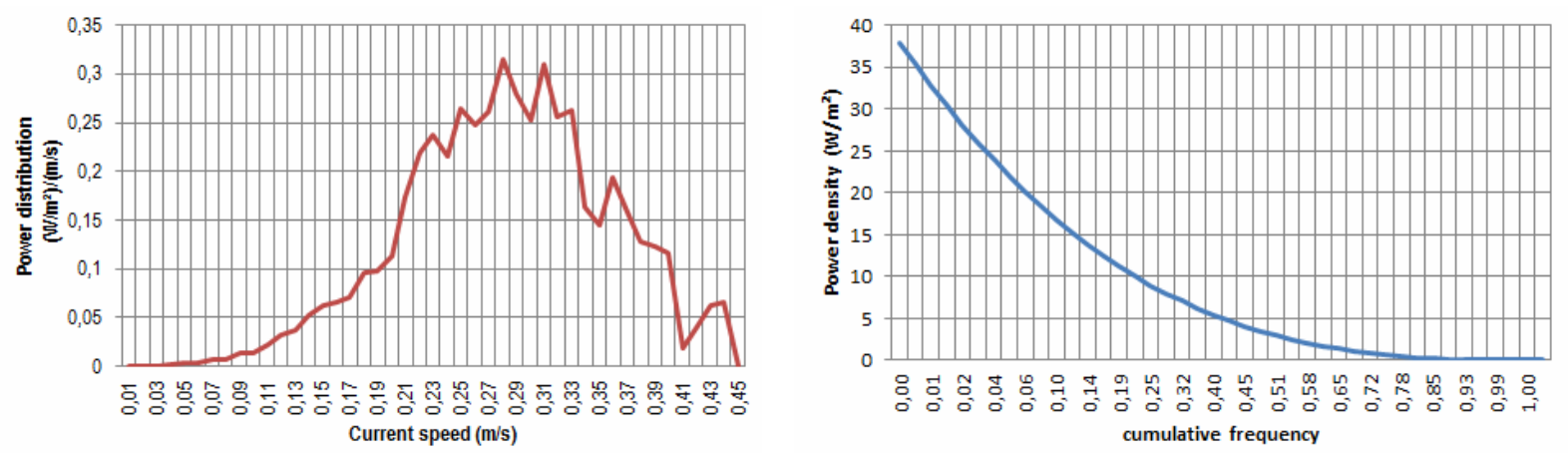

(c)

Figure 9. Power distribution as a function of current velocity and power density as a function of cumulative frequency, for the quota of $5 \mathrm{~m}$, for (a) spring 1995, (b) summer and (c) winter 1996 
Figure 10 shows the power distribution depending on the speed of current and power density as a function of cumulative frequency for the quota of 15 meters, for spring 1995, winter, autumn and summer of 1996. The distribution of power to spring 1995 for currents near the surface showed a maximum value of $0.31\left(\mathrm{~W} / \mathrm{m}^{2}\right) /(\mathrm{m} / \mathrm{s})$ that is related to a speed of $0.33 \mathrm{~m} / \mathrm{s}$ (Figure $10(\mathrm{a})$ ). The likelihood of this being equaled or exceeded speed is $3.25 \%$. The average velocity is $0.16 \mathrm{~m} / \mathrm{s}$, with a cumulative frequency of 0.47 so that the power density is equal to or exceeded $2.1 \mathrm{~W} / \mathrm{m}^{2}$.

In the summer of 1996 the velocity values are a little more intense. The power distribution for this period (Figure $10(\mathrm{~b})$ ) showed a maximum value of $0.34\left(\mathrm{~W} / \mathrm{m}^{2}\right) /(\mathrm{m} / \mathrm{s})$ for a speed of $0.36 \mathrm{~m} / \mathrm{s}$. However the probability for a speed of $0.36 \mathrm{~m} / \mathrm{s}$ being equaled or exceeded is $5.14 \%$. If we take the average speed of the data set for calculating the power density, the intensity value is $0.17 \mathrm{~m} / \mathrm{s}$. The power density is 2.52 $\mathrm{W} / \mathrm{m}^{2}$ to this speed and cumulative frequency is 0.44 .

The power distribution for fall 1996 is shown in Figure 10 (c). The maximum value of the distribution is $0.35\left(\mathrm{~W} / \mathrm{m}^{2}\right) /(\mathrm{m} / \mathrm{s})$ for a speed of $0.43 \mathrm{~m} / \mathrm{s}$, the likelihood of this velocity value to be equal or exceeded is only $1.15 \%$. It shows that the average speed for this data set was $0.14 \mathrm{~m} / \mathrm{s}$, the cumulative frequency is 0.46 with a power density of $1.41 \mathrm{~W} / \mathrm{m}^{2}$.

As occurred in the summer of 1996, data from the winter of 1996 closer to the surface, also led the speed values with greater intensity. The power distribution (Figure 10 (d)) shows a maximum value of 0.49 $\left(\mathrm{W} / \mathrm{m}^{2}\right) /(\mathrm{m} / \mathrm{s})$ for a speed of $0.48 \mathrm{~m} / \mathrm{s}$. The probability speed of $0.48 \mathrm{~m} / \mathrm{s}$ being equaled or exceeded is $15.64 \%$. The average speed is $0.2 \mathrm{~m} / \mathrm{s}$, with $42 \%$ probability that value being equaled or exceeded. For these values the power density is $4.10 \mathrm{~W} / \mathrm{m}^{2}$.

Best results will be obtained certainly ahead of the continental shelf. The Project Oscar, developed by NOAA [8], indicates on its website the results of current speed more intense, especially in positions close to the limit of the continental shelf. The values provided for surface currents are close to $1 \mathrm{~m} / \mathrm{s}$ in positions between $150 \mathrm{~km}$ and $300 \mathrm{~km}$ from the coast. These data clearly suggest the need for further studies in the region, in order to determine more accurately the energetic potential of sea currents.

These results deserve a more careful analysis regarding the possible complementarity in time with solar energy and the possible spatial complementarity with hydro energy. [12]-[13] The operation in conjunction with a reversible hydro power plant may lead to increase in capacity factor of power plants based on renewable resources. [14] It is also possible that there is a natural complementarity between wind and wave energy [15], with consequences also on the exploitation of energy from ocean currents, very interesting for the region where there are already $300 \mathrm{MW}$ of wind farms. 

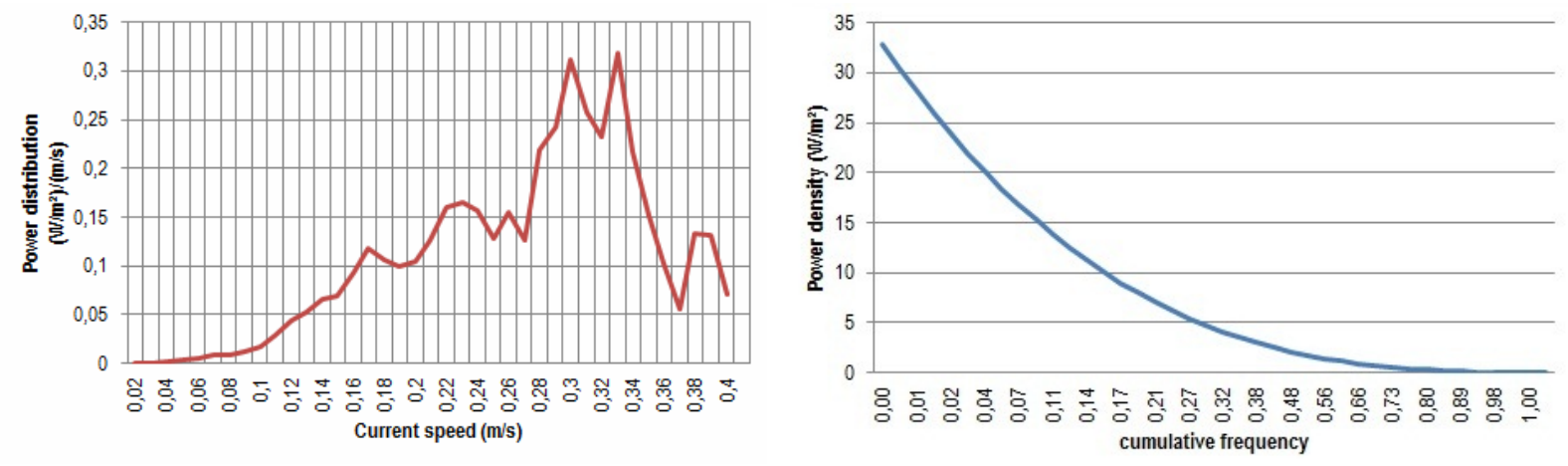

(a)
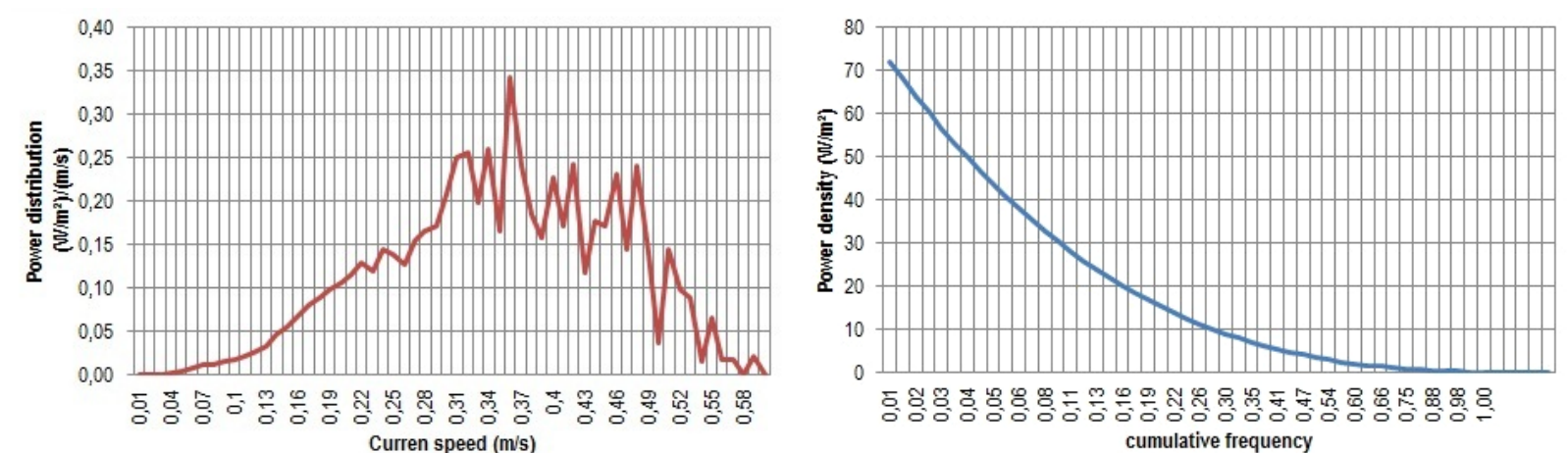

(b)
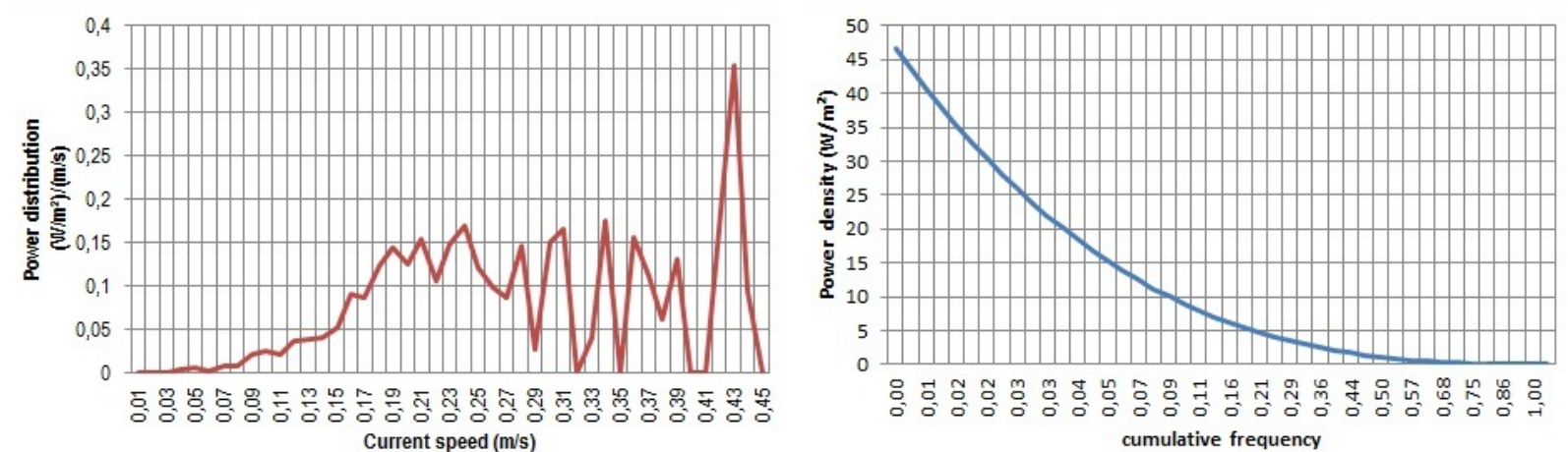

(c)
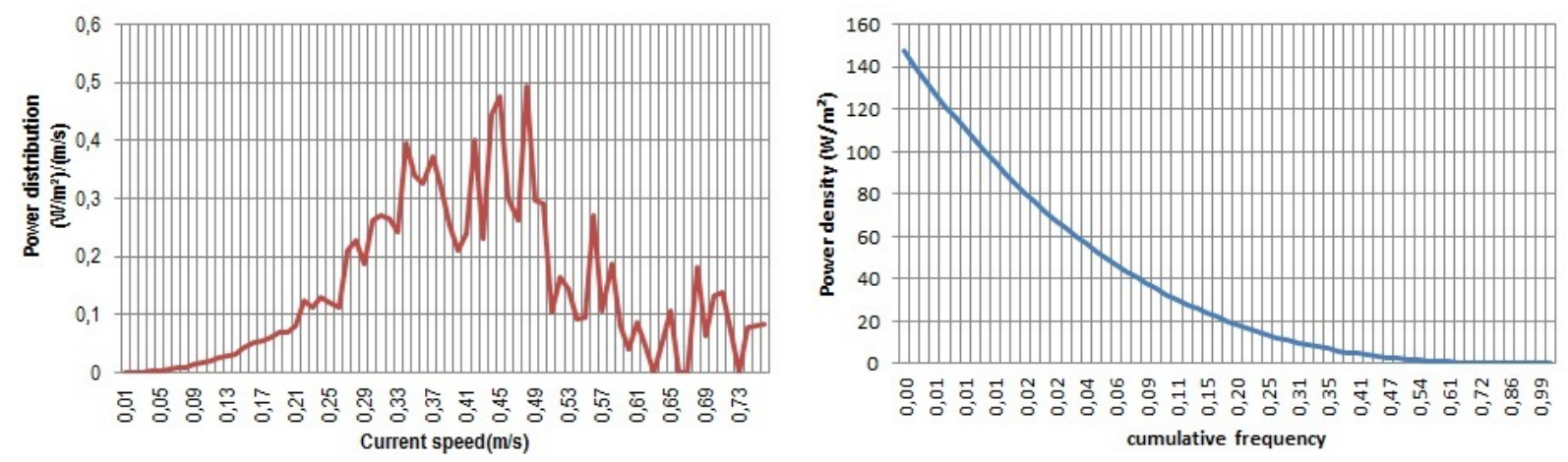

(d)

Figure 10. Power distribution as a function of current velocity and power density as a function of cumulative frequency, for $15 \mathrm{~m}$, for (a) spring 1995, (b) summer, (c) autumn and (d) winter 1996 


\section{Final remarks}

This article presented a preliminary determination of the energy potential for power generation from ocean currents along the coast of Rio Grande do Sul, the southernmost state of Brazil, based on data obtained with current meters installed in a position relatively close to the shoreline.

This article also presented notes that contribute to the characterization of the system of ocean currents in the region. The characteristics of the coast in the region allow conclusions to be extended to a length of approximately $600 \mathrm{~km}$, corresponding to the entire coast of the southernmost state of Brazil.

Unfortunately, the results do not allow optimism about the power generation from ocean currents on the southern coast of Brazil, at least over the continental shelf. The results did not exceed $0.5\left(\mathrm{~W} / \mathrm{m}^{2}\right) /(\mathrm{m} / \mathrm{s})$. Best results will be certainly obtained ahead of the continental shelf.

\section{Acknowledgements}

This work was developed as a part of research activities on marine engineering and renewable energy developed at the Instituto de Pesquisas Hidráulicas, Universidade Federal do Rio Grande do Sul. The authors acknowledge the support received by the institution.

\section{References}

[1] Assis L.E., Beluco A., Almeida L.E.S.B. On the wave energy potential along the southern coast of Brazil, 2013. Available at: http://www.beluco.net/papers/wave-energy-southern-brazil.pdf.

[2] Twidell J., Weir T. Renewable Energy Resources. $2^{\mathrm{a}}$ ed. Taylor \& Francis Group. London, 2006.

[3] Almeida L.E.S.B., Toldo Jr. E.E. Environmental studies in oceanic and coastal areas in southern Brazil, Osório, RS (in portuguese). Internal report, Inst Pesquisas Hidráulicas, Univ Fed Rio Grande do Ssul, 1997.

[4] Zembruscki S. Geomorphology of the southern Brazilian continental margin and adjacent ocean basins (in portuguese). Internal report, Project REMAC, 7, 129-174. Rio de Janeiro, 1979.

[5] Matlab for Windows User's Guide. Math Works Inc. 2006.

[6] Braga M. F., Krusche N. Standard winds in Rio Grande, RS, in the period from 1992 to 1995 (in portuguese). Atlântica 2000, 22, 27-40.

[7] Möller Jr O.O., Piola A.R., Freitas A. C., Campos E. J. D. The effects of river discharge and seasonal winds on the shelf off southeastern South America. Continental Shelf Research 2008.

[8] Palma E. D., Matano R. P., Piola A. R. A numerical study of the Southwestern Atlantic Shelf circulation: Stratified ocean response to local and offshore forcing. Journal of Geophysical Research 2008, 113, C11010.

[9] Cecílio R. O. Three-dimensional structure of the currents generated by the wind on the continental shelf of southern Brazil (in portuguese). Master dissertation, Inst Oceanográfico, Univ São Paulo, 2006.

[10] Krusche N., Saraiva J. M., Reboita M. S. Interim climatological normals from 1991 to 2000 for Rio Grande, RS (in portuguese). Imprensa Universitária 2002.

[11] Oscar, Ocean Surface Current Analyses, Real time. National Oceanic and Atmosferic Administration. Available at www.oscar.noaa.gov/. Accessed on November 2, 2012.

[12] Beluco A., Souza P.K., Krenzinger A., A dimensionless index evaluating the time complementarity between solar and hydraulic energies, Renewable Energy 2008, 33, 2157-2165.

[13] Beluco A., Souza P.K., Krenzinger A., A method to evaluate the effect of complementarity in time between hydro and solar energy on the performance of hybrid hydro PV generating plants. Renewable Energy 2012, 45, 24-30.

[14] Anagnostopoulos J.S., Papantonis D.E. Simulation and size optimization of a pumped storage power plant for the recovery of wind farms rejected energy. Renewable Energy 2008, 33, 16851694.

[15] Lakkoju V.N.M.R. Combined power generation with wind and ocean waves. WREC 1996, 870874. 


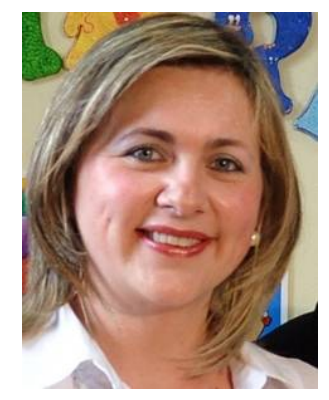

Andrea Fischer holds a degree in Agricultural Engineering from the Federal University of Pelotas (2001) and master's degree in Ocean Engineering by the Federal University of Rio Grande (2005), with a dissertation in the field of coastal morphodynamics. She is currently professor of technology education at the Federal Institute South Rio Grande, Pelotas Campus which offers courses of hydraulic and pneumatic equipment and instrumentation and industrial control. She is currently a doctoral student in the Graduate Program in Water Resources and Environmental Sanitation, Institute of Hydraulic Research (IPH / UFRGS), with a thesis in the field of power generation by ocean currents.

E-mail address: andrea@pelotas.ifsul.edu.br

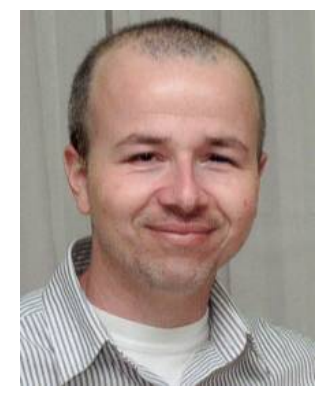

Alexandre Beluco is Doctor of Engineering, Civil Engineering and BS in Physics, and is a professor at the Institute of Hydraulic Research (IPH), UFRGS, and has activity as a researcher on renewable energy resources. He teaches courses on hydraulics and on design methods for undergraduate engineering and on planning and evaluation of experiments and on methods of design and research for the graduate course in water resources, for which also offers elective courses on natural resources and renewable energy. Currently, he serves as reviewer of Energy, Solar Energy and Renewable and Sustainable Energy Reviews and had an article recently cited by Renewable Energy Global Innovations.

E-mail address: albeluco@iph.ufrgs.br

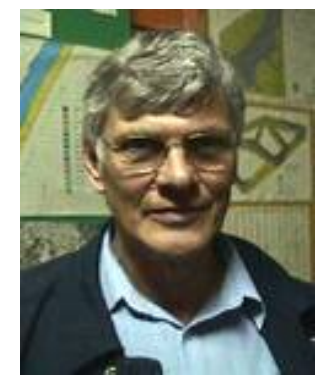

Luiz Emílio B. Almeida is graduated in Civil Engineering from the School of Engineering at Federal University of Rio Grande do Sul (1975), has specialization in Martime et Fluviale Ingenieur from Ecole Nationale des Travaux Publics de le Etat (1980) and Ph.D. in sedimentology from the University of Paris XI (Paris-Sud) (1983). Currently, he is a retired professor of the Institute of Hydraulic Research and researcher at Center for Coastal and Oceanic Geology Studies. Dr Almeida has experience in oceanography, with emphasis in physical oceanography, working on the following topics: protection of beaches, breaking waves, sediment transport.

E-mail address: luiz.almeida@ufrgs.br 